\title{
Antecedents of absorptive capacity: A proof of proposition
}

\author{
Wayan Gede Supartha \\ Faculty of Economics and Business \\ Udayana University, Indonesia \\ Ida Ayu Dewi Kumala Ratih \\ Health Polytechnic Denpasar \\ Ministry of Health of the Republic of Indonesia
}

\section{Keywords}

Absorptive capacity, creative leadership, knowledge sharing, small crafts industry

\begin{abstract}
The absorptive capacity of the craftsmen in Small Crafts Industry (SCI) to identify new value, and then assimilate and apply it for commercial purposes and win the competition is very necessary to study. This is based on observation that the absorptive capacity of the SCI is relatively low, which leads to lower competitiveness. Around 21 (twenty one) SCI in Gianyar, Bali Province, change their business into other businesses due to being unable to compete in the crafts industry and their absorptive capacity to assimilate and apply new values and new technologies is considered low.

This research aims to (1) develop the proposition concept of the influence of creative leadership towards absorptive capacity; (2) attest to the influence of the knowledge-sharing on the absorptive capacity; (3) attest to the influence of creative leadership towards knowledge sharing, and; (4) develop the concept of mediating role of knowledge sharing over the influence of creative leadership against absorptive capacity. The study was done in Gianyar Regency, with a sample of 90 Small Industry Craftsmen (SCI) in 7 (seven) subdistricts. The analysis tool used was the Partial Least Square (PLS). This research identified that the proposition which states that creative leadership influences absorptive capacity is proven positive and significant. Knowledge sharing gives a positive and significant effect on the absorptive capacity. Creative leadership significantly and positively affects knowledge sharing; furthermore, knowledge sharing has been found having partial mediating role over the influence of creative leadership on absorptive capacity.
\end{abstract}

Corresponding author: Ida Ayu Dewi Kumala Ratih

Email address for corresponding author: idadkr@gmail.com

First submission received: 3rd February 2017

Revised submission received: 21st March 2017

Accepted: 10th April 2017

\section{Introduction}

The absorptive capacity of SCI to identify new value, assimilate and apply it for commercial purposes and then winning the competition is still perceived as low. It can be seen that 21 (twenty one) SCIchange or close the business within a period of 10 (ten) years. Based on interviews with 15 (fifteen) existing SCI, it was revealed that their ability in getting information about new products, new design, new technologies, and the integrate new knowledge to produce new products belong to low category. In other words, the absorptive capacity of the SCI being observed falls into the category of low.

Several studies reveal, absorptive capacity is influenced by the knowledge sharing, while the knowledge sharing is influenced by creative leadership. Liao et. Al. (2007) stated that knowledge sharing affects absorptive capacity. Research of Gao et al. (2008) show that absorptive capacity 
significantly affects company's performance. Mahnke et al. (2005) suggest that knowledge sharing is significantly affecting the level of absorptive capacity. Then, Wuryaningrat (2013) also shows that knowledge sharing affects absorptive capacity before knowledge can be turned into Absorptive Capacity. Discussion specifically on the influence of creative leadership against the absorptive capacity has not been found so far. Nonetheless, Cohen \& Levinthal (1990) have ever pointed out that an organization requires specific knowledge, prior to assimilate and use the new knowledge (absorptive capacity) and this is driven by the creative leadership skills. This indicates creative leadership plays arole in enhancing absorptive capacity.

Creative leadership and knowledge sharing show positive relation (Reychav et al., 2012). Creative management support to improve knowledge sharing has been proven to be positive and significant. For example, employees trust and willingness of the experts to help others are highly determined by the ability of creative management (Wang \& Noe, 2010). Research on Lin (2007) shows that the support of top management influences significantly to the process of knowledge sharing. These results also show that the willingness of employees to knowledge collecting and knowledge donating allows companies to enhance absorptive capacity.

Hence, the purposes of this research are to; (1) develop the proposition concept of the influence of creative leadership against absorptive capacity; (2) attest to the influence of absorptive capacity against sharing knowledge; (3) attest to the influence of creative leadership towards knowledge sharing; (4) develop the concept of mediating role of knowledge sharing over the influence of creative leadership against absorptive capacity.

\section{Literature Review}

\subsection{Absorptive Capacity}

An organization needs specific knowledge, prior to assimilate and use the knowledge. This is termed as the absorptive capacity (Cohen \& Levinthal, 1990). Moreover, previous learning experiences can also affect performance. The ability to learn involves capacity development to assimilate existing knowledge, while the ability to solve problems means the capacity to create new knowledge or new products.

Having relevant knowledge and skills will raise creativity. Absorptive capacity not only refers to acquisition or assimilation of information by an organization, but also the ability of the organization to make use of information. Therefore, in an organization, absorptive capacity is not only about what is directly faced in the external environment, but also the knowledge needed by all individuals for making internal communication. This is very important, because diversity of knowledge structure for each individual would be beneficial for wider range of knowledge in the organization. In addition, the diverse knowledge structure will lead to occurrence of learning process for problem-solving that produces absorptive capacity (Cohen \& Levinthal, 1990).

Zahra and George (2002) point out that the absorptive capacity is a broad concept, that includes the company's overall capacity for learning, applying new knowledge, disseminating it internally, and creating a new resource, including new technologies. Zahra and George (2002) define the absorptive capacity (ACAP) as a set of routines and processes of the oganization to acquire, assimilate, transform and exploit the knowledge to produce dynamic organization capacity. Absorptive capacity is a function of human resources in the organization, for example tacit knowledge and explicit knowledge, routines, management competence, and culture, so that the organization can develop dynamically.

\subsection{Knowledge Sharing}

To understand knowledge sharing, it needs to begin with discussing the knowledge itself (Sharratt \& Usoro, 2003). When the people in the organization are given the opportunity to think, learn, and speak to each other, it will raise new ideas, based on the knowledge possessed by each individual. Hence, there will be unlimited practical knowledge within the organization. According to 
Davenport and Prusak (1998), organizations can manage the knowledge resource effectively when employees are willing to work with colleagues to contribute their knowledge to the organization; in other words, knowledge is a fluid combination of experiences, values, and contextual information.

Knowledge within the organization can be managed through knowledge management. Knowledge management $(\mathrm{KM})$ is beneficial to the interests of the manager in developing core competencies, knowledge transfer, so the information in an organization can be managed properly (Beijerse, 2000; Kalpic ¿ \& Bernus, 2006; Srivastava EGupta, 2007). Knowledge sharing is the core of $\mathrm{KM}$, because it enhances performance, innovation, as well as reduces the cost of learning (Calantone et al., 2002; Matzler \& Mueller, 2011). Small Craft Industries (SCI) is also managing knowledge, but through an informal, not formal, process. SCI should have the ability to search for and share knowledge (especially across firms), synthesize existing knowledge, and reuse or apply new knowledge (Hutchinson, 2008).

Hooff and Weenen (2004) divide the knowledge sharing (KS) into two dimensions, namely: donating knowledge and collecting knowledge. The KS capacity can be categorized into three dimensions, namely willingness to share knowledge, ability to learn, and ability to transfer knowledge (Mathuramaytha, 2012). Basic yet necessary facilities to allow employees to exchange knowledge and contribute to the application of knowledge, and finally be able to realize the Organization's competitive advantage, is under the umbrella of knowledge sharing concept (Wang \& Noe, 2010).

Kalpic and Bernus (2006) stated that knowledge is created from the data which become information as interpreted and remembered by people with a given skill, experience, and ability. Sharing is a process, in which one party provides the resources and then the resources are accepted by others. This process facilitates the creation of necessary understanding required by the recipient and allows the development of a solution (Sharratt \& Usoro, 2003). Someone will donate his knowledge if he has sharing experience embedded in the networks structure (Wasko \& Faraj, 2005). Knowledge sharing occurs at the individual and the organization level. At the individual level, knowledge sharing happens by talking to colleagues to help them work better, faster, or more efficient. At the organization level, knowledge sharing is to acquire, organize, reuse, and transfer the experience based on knowledge of the organizations and provides knowledge for others in the business (Lin, 2007). Hendriks (1999) states the knowledge sharing is something related to communication.

Thus, knowledge sharing is a process of exchange of information, knowledge, and skills of a person to others. This process includes the granting or acceptance of or a combination of absorbing and delivering a variety of information, knowledge and skills at the individual and at the organization level (Hendriks, 1999; Lin, 2007; Sharratt \& Usoro, 2003).

\subsection{Creative Leadership}

Creative leaders are leaders with full of ideas to solve problem and improve operations on an ongoing basis, having a clear picture about the future of the company and understand how to work efficiently to achieve the vision (Dahlgaard et al, 1997). Leaders have the courage and are ready to bear the risk of failure. They are not afraid to intervene in conflicts among the staff. As very inspiring leaders, intervention in the conflict between personnels gives good results.

Creative leadership style has much in common with transformational leadership (Rickards and Moger, 2000). Research on the Small Crafts Industry (SCI) needs to develop the concept of creative leadership by synthesizing and combining four transformational leadership dimensions (Avolio and Bass, 1995) with the concept of "4I". Creative leadership by Jain and Sharma (2012) can be summarized into three dimensions. This means that the idealized influence and intellectual stimulation are synthesized into creative ability, inspirational motivation, and individualized consideration. 
Creative ability is seen from the great curiosity and entrepreneurship capability of the leader. In this case, the leader is able to combine various input/ factors innovatively to produce the value of service to customers and share the risks. Reality contact takes the initiative in finding out the operating constraints and managing the crisis with confidence. Independent, is having confidence when operating in a strange situation and rejecting the status quo, as well as being courageous.

Inspirational motivation is reflected from the act of the leader to provide challenge and give meaning over the work of his subordinates, such as capable of conveying clear expectations. In addition, he is committed to organizational target and delivers a compelling vision to keep the subordinates focused on the target.

Individualized consideration is when the leader always listens intently, pays special attention to the needs of his subordinates to gain achievements. The leader also cares of the feelings and interests of his subordinates.

\section{Conceptual Framework, Propositions, and Hypotheses}

\subsection{Conceptual Framework}

The absorptive capacity is very important in maintaining the existence of the business. The company should be able to: recognize the new value new, absorb external information, then assimilate, and apply it for commercial purposes. The company is required to be more capable of managing knowledge as well as the physical assets, able to develop a thorough understanding of the existing knowledge, and convert the knowledge into the company's operational capacity.

Zahra and George (2002) state absorptive capacity is a set of routines and processes of an organization, so that the organization could acquire, assimilate, transform and exploit the knowledge to produce a dynamic organization capacity. Absorptive capacity is a function of the organization's resources, such as; tacit and explicit knowledge, competency management, routine, and culture. An organizational unit with high level of absorptive capacity tends to exploit the new knowledge to help their innovative activities. Access to external knowledge and learning capacity is necessary to enhance internal innovation and performance. The organization mechanism such as the ability to do coordination and absorb new knowledge is associated to absorptive capacity (Jansen et al., 2005).

The creative leadership shows a positive effect on absorptive capacity (Flatten et al., 2015). A creative leader is indispensable in increasing the absorption of employees' capacity by changing the production processes, using new technologies or implementing new marketing, so that the company can always compete with others and guarantee the sustainability of the company.

Knowledge sharing should be followed with the ability to absorb knowledge (absorptive capacity). If it is not supported with high absorption, the knowledge cannot be transferred. Knowledge sharing affects absorptive capacity, while absorptive capacity is significantly affecting the firm to innovate. That means a high absorptive capacity is associated with a better chance to successfully exploit new knowledge to generate more new products. Thus, knowledge sharing influences absorptive capacity. Gaoet. al. (2008) suggest that high absorptive capacity is associated with how the company exploits the new knowledge in order to introduce more new products.

Creative leaderships affect knowledge sharing. These elements consist of a platform of understanding from where new ideas bloom. Managerial intervention is required to encourage and facilitate the systematic sharing of knowledge. Creative leadership and knowledge sharing also show a positive relation. Support from management to the knowledge sharing is proven positive and significant. Creative leaders also promote knowledge distribution of the firm to the initiatives and operation that can be sources of competitive advantages.

Based on what is stated in the introduction, including phenomena, theoretical review, empirical study, this research concept can be arranged as in Figure 3.1. 


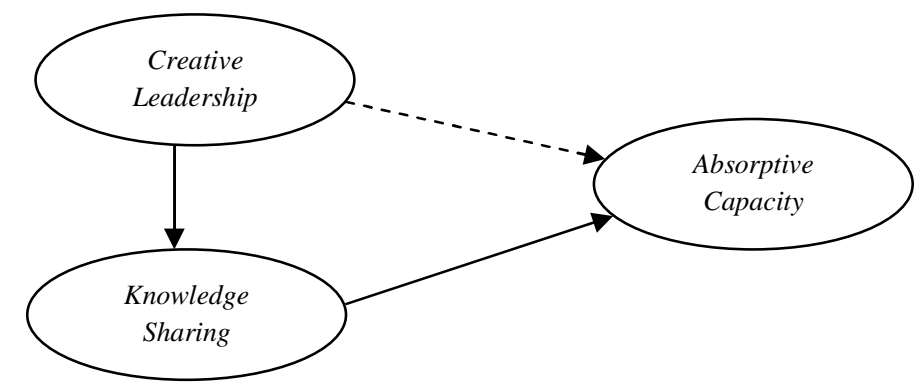

Figure 3.1.Conceptual Framework of the Research

\subsection{Proposition and Hypothesis}

\subsubsection{Proposition}

The research that specifically discusses the influence of creative leadership against absorptive capacity is hitherto unavailable. An organization requires specific knowledge, prior to assimilate and use new knowledge; it is referred to as the absorptive capacity (Cohen \& Levinthal, 1990). Furthermore, absorption as well as exploration of knowledge require creative leadership. Some research suggest that knowledge sharing has a positive and significant effect against the absorptive capacity. It can be seen from the research conducted by Cohen and Levinthal: (1990), Lane and Lubatkin (1998), Davenport and Prusak (1998), Tsai (2001), Liao et al. (2007) and Gao et al. (2008). Likewise, some empirical studies suggest that creative leadership has a positive and significant influence to knowledge sharing. It can also be seen from research done by Hsu (2008), Reychav et al. (2012), Wang \& Noe (2010) and Menkhoff et al. (2005). Based on the empirical study and the aforementioned theoretical concepts, the following propositions can be deduced.

$\mathrm{P}_{1}$ : Creative leadership shows a positive and significant effect against the absorptive capacity.

\subsubsection{Hypothesis}

\section{1) Influence of Knowledge Sharing onAbsorptive Capacity}

Cohen and Levinthal (1990) and Zahra and George (2002) argue that the absorptive capacity, the ability of companies to be aware of new value, external information, assimilate, and then apply it to commercial purposes is essential for absorption, transformation and exploitation of knowledge to enhance the capabilities and improve organizational performance (Cohen \& Levinthal, 1990; Zahra \& George, 2002; Gao et al., 2008). According to Lane and Lubatkin (1998), the company should pay more attention to its ability to manage knowledge and the physical assets. Davenport and Prusak (1998), moreover, suggest that knowledge sharing must be supported with the ability to absorb knowledge; if not supported, the knowledge would fail to be transferred. Tsai (2012) reveals that organizational units with a high level of absorptive capacity tend to utilize new knowledge from other units to help their innovative activities. Furthermore, Liao et. al. (2007) point out that knowledge sharing affects absorptive capacity. Based on the above mentioned theoretical and empirical study, the second purposedhypothesis is as follows.

$\mathrm{H}_{1}$ : Knowledge sharing shows a positive and significant effect onabsorptive capacity.

\section{2) Influence of Creative Leadership on Knowledge Sharing}

Creative leaderships explore the knowledge sharing. These elements consist of a platform of understanding from where new ideas are developed (Rickards \& Moger 2000). Managerial intervention is a must to support and facilitate the systematic knowledge sharing (Hsu, 2008). Creative leadership and knowledge sharing are related in a positive way (Reychav et al., 2012). Creative management support to improve knowledge sharing has been proven positive and significant. For example, employees' trust and the intention of experts to help others are highly determined by the creative management capability (Wang \& Noe, 2010). The main task of a creative leader is converting knowledge on something beneficial by harnessing the intellectual assets of the organization. Another step that needs to be done is to lead and promote knowledge management 
agenda by funnelling enterprise knowledge into initiatives that are expected to be a source of competitive advantage (Menkhoff et al., 2005). Based on the empirical study, the second hypothesis can be formulated as follows.

$\mathrm{H}_{2}$ : Creative leadership positively andsignificantly affects knowledge sharing.

\section{Research Methods}

\subsection{Population, Sample, and Data Sources}

This research was explanatory study and used a quantitative approach (positivism). This research was conducted in Gianyar Regency and engaging owners of Small Crafts Industry (SCI) as the research object. Site selection was based on several reasons, namely the Gianyar Regency is the Small Crafts Iindustry (SCI) centres in Bali. Gianyar Regency is also a pioneer in the development of the SCI in Bali, and as the handicraft industry included in the global market. The population in this study were all SCI in Gianyar Regency. SCIhaving employees between 1 person - 29 people amounted to 1,733 (Kabupaten Gianyar dalam Angka, 2016). The sample of 90 people respondents was considered adequate, considering that the research model was assumed to be eligible to do with $40-100$ respondents as the sample if using Component based SEM analysis techniques i.e. Partial Least Square (Chin, 1996; Henseller, 2011).

The sampling was employing Stratified Simple Random Sampling method spread in 7 (seven) districts in Gianyar Regency. The data in this study were gathered by disseminating research instrument. The answers were gathered and tabulated with Semantic Differentials (Effendi and Tukiran, 2012).

\subsection{Validity and Reliability Test on the Instruments}

This research belonged to a survey research and thus the data collection tools were research instruments. Before the data could be analyzed using Partial Least Square (PLS), validity and reliability tests were done on the instrument. Validity and reliability tests of research instrument were done by analyzing the validity and reliability of the data collected, namely 90 respondents, to get the diverse views as well as consistency of the answers of the respondents (Chin et al., 1996).

\subsubsection{Validity Test}

Validity test refers to the ability of an indicator in explaining a measureable concept. Analysis test of the indicators employed Kaiser-Meyer-Olkin Measure of Sampling Adequacy and Bartlett's Test (KMO MSA) and Anti-image Correlation with some provisions; First, the value of KMO MSA > 0.5 and significance $<5 \%$ mean the sample is already sufficient to be analyzed further; second, on the diagonal axis of anti image correlation, all must be> 0.5 , but when there is an indicator less than 0.5, it will be removed (Baruni \& Sentosa. 2013). Based on data analysis (Table 5.2.1), all dimensions/indicators have a value of KMO MSA $>0.5$. Thus, all the dimensions or the indicators being examined could be declared valid.

\subsubsection{Reliability Test}

Reliability is an instrument to test the consistency over time. It is often done in One Shot or only once measurement; if using SPSS, it is tested through Cronbach's Alpha. When the value of Cronbach's Alpha is $>0.6$, the contsruct or variable is reliable (Sekaran, 2006). Based on data analysis (Table 5.2.1), all dimensions/indicators have the value of Cronbach's Alpha > 0.6. Thus, all the dimensions or the indicators being examined can be stated reliable.

\subsection{Metode AnalisisAnalytical Method}

This research employed Component based SEM analysis technique, namely Partial Least Square (PLS). The evaluation of PLS model was conducted in two stages. The first one was to evaluate the outer model consisting of Covergent validity, Discriminant validity, and Composite reliability. Second, the inner model consisted of testing the direct and indirect (mediating) influence. 


\section{Results and discussion}

\subsection{Characteristics of Respondents}

Discussion about the characteristics of the respondents in this study consists of the company's age, gender, age, education, and business experience.

Based on the data in Table 5.1, it can be stated that the age of respondents is mostly over 50 years old $(30.00 \%)$. This means that the leadership of the Small Crafts Industry owners starts to help manage the parents' business that got increased number of visits to family-owned art shops in 1990.

Table 5.1

Characteristics of Owners of Small Crafts Industry (SCI)in Gianyar Regency

\begin{tabular}{|c|c|c|c|}
\hline No. & Respondent Characteristics & Number & Percentage \\
\hline \multicolumn{4}{|c|}{ Respondent } \\
\hline \multicolumn{2}{|c|}{ Less than 29 years old } & 6 & 6,67 \\
\hline \multicolumn{2}{|c|}{30 years old-34 years old } & 8 & 8,89 \\
\hline \multicolumn{2}{|c|}{35 years old -39 years old } & 7 & 7,78 \\
\hline \multicolumn{2}{|c|}{40 years old -44 years old } & 18 & 20,00 \\
\hline \multicolumn{2}{|c|}{45 years old -49 years old } & 24 & 26,67 \\
\hline \multicolumn{2}{|c|}{ More than 50 years old } & 27 & 30,00 \\
\hline \multicolumn{2}{|c|}{ Total } & 90 & 100,00 \\
\hline \multicolumn{4}{|c|}{ Education } \\
\hline 1. & Elementary School & 6 & 6,67 \\
\hline 2. & Junior High School & 4 & 4,44 \\
\hline 3. & $\begin{array}{l}\text { Senior High School / Vocational } \\
\text { School }\end{array}$ & 35 & 38,89 \\
\hline 4. & Diploma & 10 & 11,11 \\
\hline 5. & Undergraduate & 25 & 27,78 \\
\hline \multirow[t]{2}{*}{6.} & Post Graduate & 10 & 11,11 \\
\hline & Total & 90 & 100,00 \\
\hline \multicolumn{4}{|c|}{ Gender } \\
\hline 1. & Male & 64 & 71,11 \\
\hline \multirow[t]{2}{*}{2.} & Female & 26 & 28,89 \\
\hline & Total & 90 & 100,00 \\
\hline \multicolumn{4}{|c|}{ Business Experience } \\
\hline 1. & Less than 29 years old & 46 & 51,11 \\
\hline 2. & 30 years old-34 years old & 14 & 15,56 \\
\hline 3. & 35 years old -39 years old & 14 & 15,56 \\
\hline 4. & 40 years old -44 years old & 8 & 8,89 \\
\hline 5. & 45 years old -49 years old & 7 & 7,78 \\
\hline \multirow[t]{2}{*}{6.} & More than 50 years old & 1 & 1,11 \\
\hline & Total & 90 & 100,00 \\
\hline \multicolumn{4}{|c|}{ Company's Age } \\
\hline 1. & Less than 24 years old & 27 & 30,00 \\
\hline 2. & 25 years old -29 years old & 20 & 22,22 \\
\hline 3. & 30 years old -34 years old & 11 & 12,22 \\
\hline 4. & 35 years old -39 years old & 18 & 20,00 \\
\hline 5. & 40 years old -44 years old & 8 & 8,89 \\
\hline \multirow[t]{2}{*}{6.} & More than 45 years old & 6 & 6,67 \\
\hline & Total & 90 & 100,00 \\
\hline
\end{tabular}

Source: Primary Data (processed) 
As seen from education of the respondents, most owners of SCI(38.89\%) in Gianyar Regency are at high school/vocational high school level. Then, respondents taking undergraduate degree amount to $27.78 \%$. There are some people who got high level of education but they did not finish their study because of accepting too many orders and then having no time to finish school. This means that to be a leader in SCIin Gianyar Regency does not require higher level of education. Respondents run the business by experience.

In terms of gender, owners of SCI in Gianyar Regency are dominated by men $(71.11 \%)$. The high percentage of men as owners of SClis inseparable from the obligation of men as the husband as the backbone of the family. Furthermore, there isalso interest from them and informal education given by their parents through training the boys to make the craft since in elementary or junior high school.

Based onthe business experience, most respondents (51.11\%) have experiences of less than 29 years. Meanwhile, most SCI in Gianyar Regency have been established less than 24 years (30.00\%). This is in accordance with the market dynamics in the Gianyar Regency since 1990, where the craft from SCI were popular among tourists abroad, so many enterprises were established.

\subsection{Validity and Reliability Test on Research Data}

Testing on the validity of research data was carried out using the factor analysis test namely Kaiser-Meyer-Olkin Measure of Sampling Adequacy and Bartlett's Test (MSA KMO) and Anti-image Correlation with the following provisions. First, the value of KMO MSA is > 0.5 and the significance is $<5 \%$. It means the data are already sufficient to be analyzed further. Secondly, on the diagonal axis of anti image correlation, all must be $>0.5$. Then, the reliability test using SPSS through Cronbach's Alpha was conducted with the provisions: when the value of Cronbach's Alpha is > 0.6 (Sekaran, 2006), the constructs or variable are considered reliable.

Table5.2.1

Validity and Reliability Test on the Indicators of the Dimension

\begin{tabular}{|c|c|c|c|c|c|c|}
\hline Variable & $\begin{array}{c}\text { Dimension/ } \\
\text { Indicator }\end{array}$ & $\begin{array}{c}\text { KMO } \\
M S A v a l u e\end{array}$ & Desc. & $\begin{array}{l}\text { Cronbach's } \\
\text { Alpha }\end{array}$ & Desc. & Significance \\
\hline \multirow{4}{*}{$\begin{array}{l}\text { Absorptive } \\
\text { Capacity }\end{array}$} & Acquisition & 0,889 & Valid & 0,895 & Reliable & 0,00 \\
\hline & Assimilation & 0,813 & Valid & 0,825 & Reliable & 0,00 \\
\hline & Transformation & 0,900 & Valid & 0,902 & Reliable & 0,00 \\
\hline & Eksploitation & 0,817 & Valid & 0,829 & Reliable & 0,00 \\
\hline \multirow{3}{*}{$\begin{array}{l}\text { Creative } \\
\text { Leadership }\end{array}$} & $\begin{array}{l}\text { Creative } \\
\text { capacity }\end{array}$ & 0,886 & Valid & 0,869 & Reliable & 0,00 \\
\hline & $\begin{array}{l}\text { Inspirational } \\
\text { motivation }\end{array}$ & 0,898 & Valid & 0,880 & Reliable & 0,00 \\
\hline & $\begin{array}{l}\text { Individualized } \\
\text { consideration }\end{array}$ & 0,917 & Valid & 0,902 & Reliable & 0,00 \\
\hline \multirow{2}{*}{$\begin{array}{l}\text { Knowledge } \\
\text { Sharing }\end{array}$} & $\begin{array}{l}\text { Knowledge } \\
\text { donating }\end{array}$ & 0,939 & Valid & 0,877 & Reliable & 0,00 \\
\hline & $\begin{array}{l}\text { Knowledge } \\
\text { collecting }\end{array}$ & 0,939 & Valid & 0,877 & Reliable & 0,00 \\
\hline
\end{tabular}

Source: Primary data (processed), 2016

As displayed in Table 5.2.1., the results of validity test using the factor analysis show that the value of KMO MSA for all dimensions of each variable is 0.5 and the significance is at $<5 \%$.It indicates that the research data are valid and the sample is already sufficient to be analyzed further. Moreover, the reliability test with the factor analysis gains results where the value of Cronbach's Alpha is $>0.6$, and thus, the constructs or variables are reliable. It can also be said that all indicators constructing variables are considered valid and reliable. 


\subsection{Results of Data Analysis}

\subsubsection{Outer model testing}

There are three criteria in implementing data analysis techniques with Warp-PLS for assessing outer model i.e. convergent validity, discriminant validity and composite reliability (Ghozali, 2008). By using Warp PLS, outer model is assessed by way of looking at the convergent validity (the value of loading factors for each invalid construct). In this research, the loading factors value can be seen through the output combined loading and cross-loading. There are two criteria for judging whether the outer model qualifies convergent validity for reflective constructs namely (1) loading factor must be above 0.70 and (2) the value of $\mathrm{p}$ significant is $<0.05$ (Sholihin and Ratmono, 2013). The results of the outer loading of this research can be seen in Table 5.2.2.

Table 5.2.2: Combined Loading and Cross-Loading

\begin{tabular}{|c|c|c|c|c|}
\hline Variable & Dimension & $\begin{array}{c}\text { Absorptive } \\
\text { Capacity }\end{array}$ & $\begin{array}{c}\text { Creative } \\
\text { Leadership }\end{array}$ & $\begin{array}{c}\text { Knowledge } \\
\text { Sharing }\end{array}$ \\
\hline \multirow{4}{*}{$\begin{array}{l}\text { Absorptive } \\
\text { Capacity }\end{array}$} & Acquisition & 0,964 & & \\
\hline & Assimilation & 0,921 & & \\
\hline & Transformation & 0,957 & & \\
\hline & Eksploitation & 0,939 & & \\
\hline \multirow{3}{*}{$\begin{array}{c}\text { Creative } \\
\text { Leadership }\end{array}$} & Creative capacity & & 0,965 & \\
\hline & Inspirational motivation & & 0,962 & \\
\hline & Individualized consideration & & 0,963 & \\
\hline \multirow{2}{*}{$\begin{array}{c}\text { Knowledge } \\
\text { Sharing }\end{array}$} & Knowledge donating & & & 0,977 \\
\hline & Knowledge collecting & & & 0,977 \\
\hline
\end{tabular}

Soure: Primary data (processed), 2016

In Table 5.2.2, the whole constructs with reflective indicators generate loading factor are > 0.70 and AVE value is $>0.5$. This means all indicators or constructs are valid. Similarly, the value of Cronbach's Alpha and Composite Reliability is $>0.7$ and thus it can be stated that all indicators or constructs are reliable. Hence, we could continue to do testing of the inner model.

Table 5.2.3: Disciminant Validity

\begin{tabular}{|c|c|c|c|c|c|c|}
\hline \multirow[b]{2}{*}{ No } & \multirow[b]{2}{*}{ Variable } & \multirow[b]{2}{*}{ AVE } & \multirow{2}{*}{$\begin{array}{l}\text { Akar } \\
\text { AVE }\end{array}$} & \multicolumn{3}{|c|}{ Correlation } \\
\hline & & & & $\begin{array}{c}\text { Absorptive } \\
\text { Capacity }\end{array}$ & $\begin{array}{c}\text { Creative } \\
\text { Leadership }\end{array}$ & $\begin{array}{c}\text { Knowledge } \\
\text { Sharing }\end{array}$ \\
\hline 1 & Absorptive Capacity & 0,894 & 0,9455 & 1 & & \\
\hline 2 & Creative Leadership & 0,928 & 0,9633 & 0,699 & 1 & \\
\hline 3 & Knowledge Sharing & 0,954 & 0,9767 & 0,248 & 0,663 & 1 \\
\hline
\end{tabular}

Source: Primary data (processed), 2016

Table 5.2.3.explains that the three variables have the Average Variances Extrated (AVE) value above 0.50 and all variables have the root value of AVE higher than coefficient correlation between one variable with other variables, so that the data have good discriminant validity.

Table 5.2.4:Composite Reliability

\begin{tabular}{|c|l|c|}
\hline No & \multicolumn{1}{|c|}{ Variable } & Composite Reliability \\
\hline 1 & Absorptive Capacity & 0,971 \\
\hline 2 & Creative Leadership & 0,975 \\
\hline 3 & Knowledge Sharing & 0,970 \\
\hline
\end{tabular}

Source: Primary Data (processed), 2016 
Based on Table 5.2.4., the Composite Reliability value of all valid constructs are above 0.60.This means the data already meet the reliability criteria.

The results of the overall evaluations regarding convergent validity, discriminant validity, and composite reliability suggest that the indicators as latent variables are valid and reliable measurement indicators.

\subsubsection{Inner Model Testing}

The inner model describes the relationship between latent variables based on substantive theory. In assessing the model with PLS, it starts with looking at R-squares for each latent variable. The results of inner model are to see the relationships between constructs by comparing the significance value with R-squares of the research model (Ghozali, 2008).

Table5.2.5-R-Square Value and Communality

\begin{tabular}{|c|c|c|}
\hline Variable & R-Square & Communality \\
\hline Absorptive capacity (ACAP) & 0,764 & 0,855 \\
\hline Knowledge sharing (KS) & 0,439 & 0,930 \\
\hline Average & $\mathbf{0 , 6 0 1}$ & 0,892 \\
\hline
\end{tabular}

Source: Primary data (processed), 2016.

Table 5.2.5 shows that the R-Square value of knowledge sharing is 0.439 ; the interpretation is that the latent variable of creative leadership has a moderate influence against the latent variable of knowledge sharing, while the R-Square of absorptive capacity variable is 0.764 . This means creative leadership has a strong influence towards the absorptive capacity.

1) Testing on $Q-S q u a r e$ predictive relevance $\left(Q^{2}\right)$

According to the analysis of the multivariate determination coefficient written as $\mathrm{Q}^{2}$, the research model is considered feasible, with detailed formula as follows.

$$
\begin{aligned}
& \mathrm{Q}^{2}=1-\left(1-\mathrm{R}_{1}^{2}\right)\left(1-\mathrm{R}_{2}^{2}\right) \\
& \mathrm{Q}^{2}=1-(1-0,439)(1-0.764)=0.8669
\end{aligned}
$$

The result shows that the value of $\mathrm{Q}^{2}$ is $0.8669(87 \%) . \mathrm{Q}^{2>} 0$ indicates that the research model is classified as a very strong model with very good observation. Thus, 87 percent of the relations among the variables can be explained by the model, while the remaining 13 percent is explained by i.e. factor error or other factors not included in the research model (Latan \& Ghozali, 2012:88).

\section{2) Testing of Goodness of Fit (GoF)}

To measure the model as a whole as a single measure of the outer model and the inner model, the value of Goodness of Fit (GoF) is chosen. The value ranges between 0 to 1 . Ghozali and Latan (2012:88) reveal that the strength of the model is determined by the Go F value namely: 0.10 means small GoF; 0.25 means medium GoF; 0.36 means large GoF. GoF is calculated from the square root of average communality indexandaverage R-Square $\left(\mathrm{R}^{2}\right)$ in Table 5.3. The formula used to calculate the value of goodness of fit $(\mathrm{GoF})$ is as follows.

$$
\begin{aligned}
\mathrm{GoF} & =\sqrt{\left(\overline{\text { Com } \left.\times \mathrm{R}^{2}\right)}\right.} \\
& =\sqrt{(0,892 \times 0,601)} \\
\mathrm{GoF} & =0,73
\end{aligned}
$$

GoF value of 0.73 shows the overall model is very fit. Thus, the path model can provide sufficient information to look at the interdependence as a whole between research variables included in the research model. 


\subsubsection{Testing on Hypotheses and Propositions}

The relationship between exogenous variable (creative leadership) and the endogenous variables (knowledge sharing and absorptive capacity) was tested statistically. It shows that one of the propositions and two formulated hypotheses have a significant influence, because based on the $t$ test criteria of $5 \%$ or 1.96 , the $t$ table is still greater than the $t$ statistics from the calculation of the Smart PLS. The result of statistical testing on the influences between variables can be seen in Table 5.2.6.

Table 5.2.6- T Statistics of Relation among Variables

\begin{tabular}{|c|c|c|c|c|c|}
\hline Variable & $\begin{array}{c}\text { Original } \\
\text { Sample } \\
\text { (O) }\end{array}$ & $\begin{array}{c}\text { Standard } \\
\text { Deviation } \\
\text { (STDEV) }\end{array}$ & $\begin{array}{c}\text { Standard } \\
\text { Error } \\
\text { (STERR) }\end{array}$ & $\begin{array}{c}\mathbf{t} \\
\text { Statistics }\end{array}$ & Description \\
\hline CL -> ACAP & 0,844 & 0,063 & 0,063 & 13,3968254 & Significant \\
\hline KS -> ACAP & 0,632 & 0,089 & 0,089 & 7,1011236 & Significant \\
\hline CL -> KS & 0,618 & 0,076 & 0,076 & 8,13157895 & Significant \\
\hline CL -> KS -> ACAP & 0,164 & 0,059 & 0,059 & 2,77966102 & Significant \\
\hline
\end{tabular}

Source: Primary Data (processed), 2016

\subsubsection{Direct Relation}

\section{1) Directly Influence of Creative Leadership variable towards Absorptive Capacity}

From the result of hypothesis testing, the influence of creative leadership,against absorptive capacity demonstrates the path coefficient of 0.844 with t- statistics of 13.3968 . The t-statistic is greater than the $\mathrm{t}$-table of 1.988 , meaning that there is a positive and significant influence of creative leadership against absorptive capacity.

2) Direct influence of variable knowledge sharing towards absorptive capacity

The hypothesis testing resultsuggests that the influence of knowledge-sharing on absorptive capacity shows a path coefficient of 0.632 with the t-statistic of 7.1011. The t-statistic is greater than the $t$-table of 1.988, meaning that there is a positive and significant influence of knowledge-sharing against the absorptive capacity.

3) Direct influence of creative leadership variable towards knowledge sharing

The result of hypotheses testing suggests that the influence of creative leadership towards knowledge sharing displays a path coefficient of 0.616 with the t-statistic of 8.1315 . The $t$-statistic is greater than the t-table of 1.988 which shows that there is a positive and significant influence of creative leadership towards knowledge sharing.

5.3.5. The relation between creative leadership and absorptive capacity variables mediated by knowledge sharing variable

An indirect relation between creative leadership and absorptive capacity variables through knowledge sharing is explained in Table 5.1 and Figure 5.2.6. Based on Table 5.2.6, the relation between CL KS AAP is ver fit. Hence, there is mediation through knowledge sharing as shown in Figure 5.1.
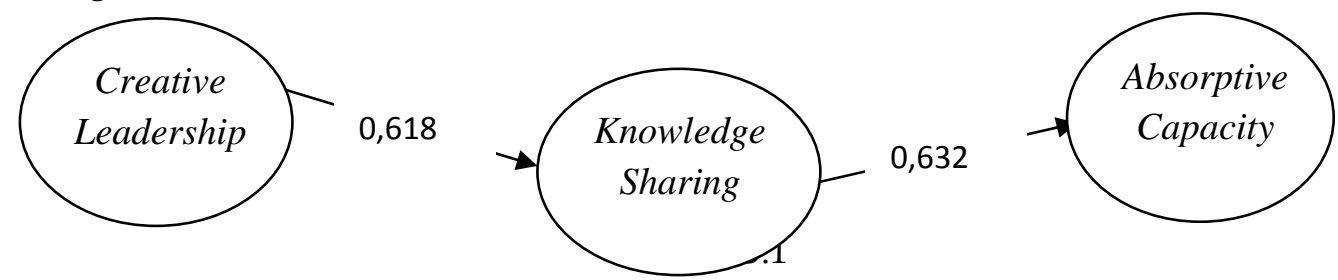

Indirect Relation between Creative Leadership and Absorptive Capacity

\subsubsection{The Effect Size $\left(\mathrm{f}^{2}\right)$ Testing}

Testing on effect size $\left(\mathrm{f}^{2}\right)$ aims to find out the goodness of mediator in this case to identify how influential the role of knowledge sharing as a mediator of the relationship between creative 
leadership and absorptive capacity. Cohen (1988) states the range of effect size is between 0.02-0.15 (weak influence), between $0.15-0.35$ (moderate influence), and $>0.35$ (strong influence).

The formula to calculate $\mathrm{f}^{2}$ is as follows.

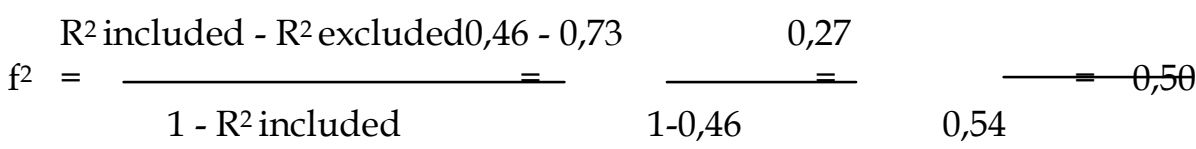

Description:

$\mathrm{R}^{2}$ included $=\mathrm{R}^{2}$ value obtained when exogenous variables are inserted to the model

$R^{2}$ excluded $=R^{2}$ value obtained when exogenous variables are removed from the model

The above measurement shows that knowledge sharing has a strong role as a mediator of the relationship between creative leadership and Absorptive Capacity.

\subsection{Discussion}

\subsubsection{The Influence of Creative Leadership against Absorptive Capacity}

Test results ofproposition testing prove that creative leadership is directly influential and has positive and significant effect to absorptive capacity. Creative ability owned Small craft industry Craftsmen (SCI) is very good/enough to realize the Absorptive Capacity within an organization, considering that the ideas or creative solutions have been successfully implemented. Creative leadership is not only at the level of ideas, but implemented operationally in the response and positive support from all employees.

The results of this study are in line with the findings of previous research by Cohen \& Levinthal (1990) that the absorptive capacity requires creative leaders who understand how to develop resources for creativity. This is because most respondents $(49.2 \%)$ only finished high school, with lack of opportunity for leaders/owners of SCIto attend practical or management training, and prefer to consider making mistakes as part oflearning experiences, so that the owners as well as employees are less able to develop their capacity. Furthermore, they also have limitations to adapt to the development of resources and changes in market demand. This can be explained according to the theory of Dynamic Capabilities by Teece and Pisano (1994) related to competencies that allow the company to create new products and processes, to respond to market changes for competitive advantage. Most respondents in this study only attended high school and have no sufficient competence to adapt to environmental changes quickly while the competition is getting tougher.

The result of interviews with craftsmen in SCI suggest that in the industry, creative leaders are those who have great curiosity, embody ideas into a new and valuable product for consumers, complete challenging tasks, dare to take risks, initiate an idea to speed up the production process at the good quality SCI by means of combining the methods of making hand madecraft with the use of sophisticated tools. The employees are challenged with high standards, managing the crisis with high confidence, while the leaders also identify the needs of their employees (Ancok, 2012; Avolio \& Bass, 1995; De Jong, \& Den Hartog 2007; Jain \& Sharma, 2012; Phipps et al., 2002; Pratoom \& Savatsomboon; Williams \&Foti, 2011).

\subsubsection{The influence of Knowledge Sharing on Absorptive Capacity}

This research managed to identify the pattern of relation between knowledge sharing and absorptive capacity as research recommendations. The questions on the knowledge sharing are listed in the dimension variables of (a) knowledge donating and (b) knowledge collecting as a positive and significant impact towards the occurence ofabsorptive capacity. The result is in line with the findings of research by Hooff and Weenen (2004) where the loading factor of knowledge collecting and knowledge donating seems to be equally strong to form the constructs of knowledge sharing, especially in the indicators of telling about new things, and sharing skills if being asked. 
Previous research by Nonaka (1994) suggests that the emergence of absorptive capacity within an organization is when employees share their knowledge. The willingness of employees to donate and collect knowledge significantly is related to Absorptive Capacity within a company. Absorptive Capacity involves the process of knowledge sharing that allows the implementation of new ideas, processes, products, or services(Cavusgil et al., 2003; Hana, 2013; Liao et al., 2007; Lin 2007; Wang \& Wang, 2012).

According to Hsu (2008) the practice of knowledge sharing in any organization is very important to learn new techniques, improvee core competencies, solve problems, and initiate a new situation. The practice of knowledge sharing where employees share and combine the knowledge in the organization will impact on the application of Absorptive Capacity, and be eventually associated with the performance of the company (Al-Husseini \& Elbeltagi, 2013; Mathuramaytha, 2012; Reychav et al., 2012; Seidler-de \& Hartmann, 2008; Wang \& Wang, 2012). A creative organization tends to support the exchange of ideas across business functions. Tacit knowledge and explicit knowledge sharing deliver powerful effects, both positive and negative, on the process of transformation of new ideas to strengthen the Absorptive Capacity (Shahin and Zeinali, 2010).

\subsubsection{The Influence of Creative Leadership towards Knowledge Sharing}

This research proves the second hypothesis as the third research objective, that is, creative leadership shows a positive and significant effect to knowledge sharing. The bigger role of the creative capacity which exerts influence towards knowledge sharing implies there is imbalance between constructs, indicated by the less attention of leaders to needs of the employees. This is apparent from the statement in individualized consideration; the respondent's perceived making mistakes as part of learning experiences. If both statements are weakening in the future, the chance to realize knowledge sharing will be hampered. Even so, the role of the creative capacity (KR) which is currently proved to be dominant in encouraging the strengthening of knowledge sharing.

The research finding is in line with what is stated in the previous research, namely the research of Rickards and Moger (2000) that creative leadership explores the knowledge sharing. These elements consist of a platform of understanding from where new ideas bloom. Managerial intervention is required to encourage and facilitate the systematic knowledge sharing of (Hsu, 2008). Thus, creativity and knowledge sharing are positively interrelated (Reychav et al., 2012).

Knowledge sharing can be stronger if supported by the top management. Knowledge can facilitate creative thinking, while creative team is developed by knowledgeable employees. By sharing their knowledge, Absorptive Capacity can be carried out (Hana, 2013; Williams \& Foti, 2011). The main duty of creative leaders is converting knowledge on something beneficial by harnessing the intellectual assets of the organization. Another thing that needs to do is to lead and promote knowledge management agenda by communicating a creative idea which hopefully can be a source of competitive advantages, unlimited knowledge and sharing information. Knowledge sharing might take place during training, consultation, collaboration and joint projects, etc. (Menkhoff et al., 2005).

5.4.4. The role of Knowledge Sharing mediates the Influence of Creative Leadership on Absorptive Capacity

The study findings describe that knowledge sharing mediates the influence of creative leadership against absorptive capacity at SCI in a positive and significant way. The role of knowledge sharing in enhancing absorptive capacity is smaller than with creative leadership role in improving knowledge-sharing on SCI. In this case, the leaders coordinate the employees to tell new things, share skills and knowledge so that the absorption of new knowledge new ideas become more advanced that in the end would create new products.

The study also found that SCI implementing creative leadership are able to manage the business very well, because they have a great curiosity, the idea to speed up the production process, manage the crisis with high confidence, challenge employees with a higher standard that inspire 
employees. This is reflected in the results of research, where the mediating role of knowledge sharing with the effect size testing shows at 0.37 , and thus it is considered strong.

Research findings proposed by Reychav et. Al. (2012) that show knowledge sharing serves as the creative influence of leadership against absorptive capacity in line with the findings of this research. Things that were delivered by Rickards and Moger (2000) which states that creative leadership explores the knowledge sharing as a center for developing new ideas. Absorptive capacity may be executed properly if supported by top management, with the support of knowledgeable employees. New product development is realized along with knowledge sharing and absorptive capacity (Hana, 2013). In addition, the leaders who transmit knowledge in a company can be a source of competitive advantage (Menkhoff et al., 2005).

Wang and Wang (2012) state that managers should pay attention to knowledge sharing as their efforts together with the employees', will change the status quo that will influence the implementation of absorptive capacity. Knowledge sharing can be emphasized on the sharing of lessons learned, not on the mistakes committed. To be able to understand the market dynamics, creative leaders should share their expertise and creative abilities to lead creative employees better and solve problems more appropriately that result in new products (Tsai, 2012).

\subsection{Limitations of the Research}

This research used a list of questions as the research instrument and was conducted in 2016, so that this study cannot be used as a guideline for monitoring and evaluation on creative leadership, knowledge sharing and absorptive capacity on SCIin the future. It is because research on perception can undergo a number of changes from various indicators that shape it in the future. This study can only give an overview about the whole character of absorptive capacity in the current year, and thus the longitudinal research needs to be conducted. The other limitation is on the methodology chosen, as it only interviews and evaluates one person, namely the leader/owners of SCI.

\section{Summary and implication of the research \\ 6.1. Summary}

Based on the results of the analysis and discussions, several things can be summed up as follows; First, creative leadership possesses a significant and positive effect on absorptive capacity if it is supported by creative capability, inspirational motivation, and individualized consideration, as well as provides the opportunity for employees to learn and see mistakes as part of learning experiences. Creative leadership will stop at the level of ideas if not followed with positive responses and support from employees as the executors.

Second, good implementation of knowledge sharing in knowledge collecting and knowledge donating variables is proven to increase absorptive capacity. This shows that telling new things, learning something new from your friends, sharing necessary skills can increase the absorption will be new processes, new technology so that it is able to produce new products.

Third, creative leadership is useful to boost the knowledge sharing. This indicates a creative leadership being constructed using three sub questions of creative capacity dimension, inspirational motivation, and individualized consideration may higher the chance of the occurrence of knowledge collecting and knowledge donating.

Fourth, creative leadership at SCI is not proven to be directly and significantly influential in enhancing absorptive capacity, but it demands a mediating role of knowledge sharing. The knowledge sharing is as a complete mediation of creative leadership against the absorptive capacity of products or processes. Creative leadership has a larger role in the knowledge sharing, compared to the knowledge sharing against the absorptive capacity, by means organizing employees to tell about new things, share skills, as well as spread knowledge in order to make SCI possessing the increasingly strong absorptive capacity so as to generate new products. 


\subsection{Implications of the Research}

\subsubsection{Theoretical Implications}

This research enriches literature on the mediating role of knowledge sharing on the influence of creative leadership against absorptive capacity. The findings of this study are able to expand the concept of creative leadership in explaining the absorptive capacity since creative leadership indicators in this research are the combination of creative capacity, inspirational motivation, and individualized consideration. The implication of this research is that the mapping of knowledge sharing as a mediator linking creative leadership and absorptive capacity constructs relatively does not show any differences in value. Therefore, the dynamics of creative leadership has been reinforced by knowledge sharing constructs which are able to embody the idea of creative leadership into the strengthening of knowledge sharing that impact absorptive capacity.

\subsubsection{Practical Implications}

After the results and discussion of the research have been stated above, several recommendations are given for SCI actors. There are some important indicators that need to be managed by the leaders or owners of SCI in Gianyar Regency to promote absorptive capacity through creative leadership and knowledge sharing. It is vital for the owners to upgrade their creativity by increasing curiosity, embody ideas into a new product that is valuable for consumers, considering to speed up the production process, managing the crisis with high confidence, avoiding the status quo, and identifying the constraints. Inspirational motivational dimensions which need to be improved are namely involving employees in problem solving and challenging employees with higher standard. In terms of individualized consideration dimension, they could see making mistakes as part of learning experience, analyzing employees' needs, and allowing employees to take a lesson.

Knowledge sharing raises new knowledge by means of knowledge collecting and knowledge donating. This involves skill sharing, knowledge sharing, and peer learning. With the improved knowledge sharing within SCI in Gianyar, both owners and employees could gain more new insight. Those efforts could also develop dynamic capabilities of SCI in Gianyar Regency in creating unique yet quality products with originality that is not easy to imitate.

\section{References}

Al- Husseini, S. and Elbeltagi, I. 2013. Knowledge Sharing Practices as a Basis of Product Innovation: A Case of Higher Education in Iraq. International Journal of Social Science and Humanity, Vol. 5, No. 2, February 2015.p.p.182-185.

Ancok, Dj. 2012. Psikologi Kepemimpinan \& Inovasi. Jakarta : Penerbit Erlangga.

Avolio, B.J. and Bass, B. 1995. Multifactor Leadership Questionnaire. Include Actual form and Ought form and Scoring Guide. Published by Mind Garden, Inc.

Baruni, W. and Sentosa, I. 2013. The Effect of Auditing Firms and Tax Legislations In Implementing The International Accounting Standards In Libya. International Journal of Business and Management Invention. Vol. 2 (10): 05-18.

Beijerse, R.P.uit. 2000. Knowledge management in small and medium-sized companies: knowledge management for entrepreneurs Journal of Knowledge Management. Vol. 4 (2): 162-179.

Calantone, Roger J., Cavusgil S.Tamer, dan Zhao, Yushan. 2002. Tacit Knowledge transfer and firm Innovation Capability. The Journal of Business $\mathcal{E}$ Industrial Marketing, Vol.18 (1): 6-21.

Cavusgil S.Tamer, Calantone, Roger J. dan Zhao, Yushan. 2003. Tacit Knowledge transfer and firm Innovation Capability. The Journal of Business $\mathcal{E}$ Industrial Marketing, Vol.18. No.1.pg. 6-21.

Chin, W.W., Marcolin, B.L., and Newsted, P.R. 1996. A Partial Least Squares Latent Variable Modeling Approach for Measuring Interaction Effects: Results From A Monte Carlo Simulation Study And Voice Mail Emotion/Adoption Study.MIS Quarterly, Information Systems Research, Management Science, pp. $21-40$. 
Cohen, Wesley M. dan Levinthal Daniel A.1990. Absorptive Capacity : A New Perspective on Learning and Innovation. Administrative Science Quarterly, Vol. 35 (1): 128-152.

Dahlgaard, J. J.,Larsen, H. Z.\& Norgaard, A.1997. Leadership Profile in Quality Management: a Danish perspective, Total Quality Management, 8, pp.S16-S30

Davenport, Thomas H. and Prusak, Lawrence. 1998. Working Knowledge: How Organizations Manage What They Know. Harvard Business Press, Boston.

De Jong, Jeroen P.J. \& Den Hartog, Deanne N. 2007. How leaders influence employees' innovative behaviour. European Journal of Innovation Management Vol. 10 No. 1, pp. 41-64.

Effendi, Sofian dan Tukiran. 2012. Metode Penelitian Survei. Jakarta: Penerbit LP3ES.

Flatten, T., Adams, D., and Brettel, M. 2015. Fostering absorptive capacity through leadership: A cross-cultural analysis. Journal of World Business . Vol. 50: 519-534

Gao Shanxing; Xu Kai; Yang Jianjun. 2008. Managerial ties, absorptive capacity, and innovation. Asia Pacific J. Manage. Vol. 25: 395-412.

Grant, Robert M. 1996.Toward a Knowledge-based Theory of the Firm. Strategic Management Journal. Vol. 17: 109-122.

Hana, Urbancova. 2013.Competitive Advantage Achievement through Innovation and Knowledge. Journal of Competitiveness, Vol. 5. Issue 1.p.p.82-96.

Hendriks, Paul. 1999. Knowledge and Process Management Volume 6 Number 2 pp 91-100.

Henseler, J., Ringle, C.M. and Sinkovics, R. R., 2009. The Use of Partial Least Squares Path Modeling in International Marketing. New Challenges to International Marketing Advances in International Marketing, Volume 20, 277-319

Hooff, Van den Bart and Van Weenen, Femke de Leeuw. 2004. Committed to Share : Commitment and CMC Use as Antecedents of Knowledge Sharing. Knowledge and Process Management, Volume 11 Number 1 pp 13-24

Hsu, I - Chieh. 2008. Knowledge sharing practices as a facilitating factor for improving organizational performance through human capital: A preliminary test . I-Chieh Hsu *,1. / Expert Systems with Applications 35 (2008) 1316-1326.

Hutchinson, Vicky dan Quintas, Paul. 2008. Do SMEs do Knowledge Management? Or Simply Manage what they Know?. International Small Business Journal. Vol. 26 (2): 131-154.

Jain, Ravindra and Sharma, Pragya. 2012. Creative Abilities of Indian Managers and Blocks to Creativity Enhancement: An Empirical Study. Management and Labour Studies. 37(1) 1-16.

Jansen, Justin J. P., Van Den Bosch, Frans A. J. and Henk W. Volberda. 2005. Managing Potential and Realized Absorptive Capacity: How Do Organizational Antecedents Matter?.The Academy of Management Journal. Vol. 48 (6): 999-1015.

Kohlbacher, Markus; Weitlaner Doris; Hollosi,Arno; Gru“nwald, Stefan and Grahsl, Hans-Peter. 2013. Innovation in clusters: effects of absorptive capacity and environmental moderators. International Business Journal. Vol. 23 (3): 199-217.

Lane, Peter J. and Lubatkin, Michael. 1998. Relative Absorptive Capacity and Inter organizational Learning Strategic Management Journal. Vol. 19: 461-477.

Latan, Hengky dan Ghozali, Imam. 2012. Partial Least Squares Konsep, Teknik, dan Aplikasi Smart PLS 2.0 $0^{\mathrm{M} 3}$ Untuk Penelitian Empiris. Semarang: Undip

Liao, Shu-hsien; Fei, Wu-Chen and Chen, Chih-Chiang.2007. Knowledge sharing, absorptive capacity, and innovation capability: an empirical study of Taiwan's knowledge-intensive industries. Journal of Information Science; 33; 340 originally published online Mar 23, p.p. 340-359. DOI: 10.1177/0165551506070739

Lin Hsiu-Fen. 2007. Knowledge sharing and firm innovation capability: an empirical study. International Journal of Manpower. Vol. 28 No. 3/4.p.p.315-332. 
Mahnke Volker, Pedersen Torben and Venzin Markus. 2005. The Impact of Knowledge Management on MNC Subsidiary Performance: The Role of Absorptive Capacity. Management International Review. Vol. 45 (2): $101-119$.

Mathuramaytha,Chonticha.2012. Developing Knowledge-Sharing Capabilities Influence Innovation Capabilities in Organizations - a Theoretical Model. International Conference on Education and Management InnovationIPEDR Vol.30. p.p. 285- 291. IACSIT Press, Singapore.

Matzler, Kurt dan Mueller, Julia. 2011. Antecedents of knowledge sharing - Examining the influence of learning and performance orientation. Journal of Economic Psychology. Vol.32: 317-329.

Menkhoff, Thomas ; Chay,YueWah; Evers, Hans-Dieter; dan Loh, Benjamin. 2005. Research Collection Lee Kong Chian School Of Business.Available at:

http://ink.library.smu.edu.sg/lkcsb_research/2738

Nonaka, Ikujiro. 1994. A Dynamic Theory of Organizational Knowledge Creation. Organization Science/ Vol.5, No. 1.

Phipps Simone T. A.; Prieto, Leon C. and Verma, Satish. 2012. Holding The Helm: Exploring The Influence Of Transformational Leadership On Group Creativity, and The Moderating Role Of Organizational Learning Culture. Journal of Organizational Culture, Communications and Conflict, Volume 16, Number 2, pg. 135-145.

Pratoom, Karun \& Savatsomboon, Gomon. 2012. Explaining factors affecting individual innovation:The case of producer group members in Thailand. Asia Pac J Manag. 29:1063-1087

Reychav, Iris; Stein, Eric W.; Weisberg, Jacob; and Glezer Chanan. 2012. The Role of Knowledge Sharing in Raising the Task Innovativeness of System Analysts. International Journal of Knowledge Management, 8(2), pg.1-22.

Reychav, Iris; Stein, Eric W.; Weisberg, Jacob; and Glezer Chanan. 2012. The Role of Knowledge Sharing in Raising the Task Innovativeness of System Analysts. International Journal of Knowledge Management. Vol. 8(2): 1-22.

Rickards, Tudor and Moger, Susan. 2000.Creative Leadership Processes in Project Team Development: An Alternative to Tuckman's Stage Model. British Journal of Management, Vol.11, pg. 273-283

Seidler-de, A.R. and Hartmann, E.2008. The use of tacit knowledge within innovative companies: knowledge management in innovative enterprises. Journal of Knowledge Management. Vol. 12 No. 1.

Sekaran, Uma. 2006. Metode Penelitian untuk Bisnis.(Kwan Men Yon, Pentj.). Edisi 4. Buku 2. Jakarta: Salemba Empat.

Shahin, Arash \&Zeinali, Zahra. 2010. Developing a relationship Matrix for Organizational Learning and Innovativeness: With A Case Study in a Manufacturing Company. International Journal of Business and Management. Vol. 5, No.7.

Sharratt, Mark and Usoro, Abel. 2003. Understanding Knowledge-Sharing in Online Communities of Practice. Electronic Journal on Knowledge Management. Vol.1 (2): 187-196.

Sharratt, Mark and Usoro, Abel. 2003.Understanding Knowledge-Sharing in Online Communities of Practice. Electronic Journal on Knowledge Management, Volume 1 Issue 2, pg. 187-196

Srivastava, Anil Gupta, Raj Karan. 2007. Leveraging knowledge management for organizational innovation and creativity. Conference on Global Competition $\mathcal{E}$ Competitiveness of Indian Corporate.

Teece, David and Pisano, Gary. 1994. The Dynamic Capabilities of Firms: an Introduction Industrial and Corporate Change, Volume 3, Number 3. 1994USA

Tsai, Kuan Chen. 2012. Creative Leadership for Directing Changes. Business Management and Strategy ISSN 2161-7104. Vol. 3, No. 2, pg76-84

Wang, Sheng dan Noe, Raymond. A. 2010.Knowledge sharing: A review and directions for future research. Human Resource Management Review: 115-131. 
Wang, Zhining dan Wang, Nianxin. 2012. Knowledge sharing, innovation and firm performance Expert Systems with Applications 39, 8899-8908.

Wasko, Molly, McLure dan Faraj, Samer. 2005. Why should I share? Examining social capital and knowledge contribution in Electronic network of practice. MIS Quarterly. Vol. 29 (1): 35-57.

Williams, Felice and Foti, Roseanne J. 2011. Formally Developing Creative Leadership as a Driver of Organizational Innovation. Advances in Developing Human Resources XX(X) 1-18

Wuryaningrat, Nikolas Fajar. 2013. Knowledge Sharing, Absorptive Capacity and Innovation Capabilities:An Empirical Study on Small and Medium Enterprises in North Sulawesi, Indonesia. Gadjah Mada International Journal of Business. Vol. 15 (1): 61 - 78.

Zahra, Shaker, A. dan George, Gerard. 2002. Absorptive Capacity: A Review, Reconceptualization, and Extension. The Academy of Management Review. Vol. 27 (2): 185-203.

Zhang, Xiaomeng and Bartol, Kathryn M.2010. Linking Empowering Leadership And Employee Creativity: The Influenceof Psychological Empowerment, Intrinsic Motivation, and Creative Process Engagement Academy of Management Journal, Vol. 53, No. 1, pg.107-128. 